\author{
М. Афанасьєва, \\ доктор юридичних наук, доцент, \\ професор кафедри конституційного права \\ Національного університету «Одеська юридична академія»
}

\title{
ПОЗИТИВНА ТА ЗВОРОТНА ДИСКРИМІНАЦІЯ У ВИБОРЧІЙ СФЕРІ
}

Серед суспільних груп завжди існують ті, які за певною захищеною ознакою об'єктивно перебувають у менш вигідному становищі, у зв'язку з чим належать до уразливої категорії. Уразливі групи об'єктивно потребують захисту й підтримки з боку держави, саме тому міжнародні та, зокрема, європейські антидискримінаційні стандарти дозволяють і можуть навіть вимагати від держав використовувати за певних обставин позитивні дії (у правозахисній системі $\mathrm{OOH}$ такі дії називають «особливими заходами», у праві $€ C$ - «спеціальними заходами»), щоб рівність, передбачена в праві, стала правовою реальністю.

Позитивні дії спрямовані на усунення дисбалансу між можливостями різних категорій осіб реалізовувати права через усталені стереотипи, практики чи традиції, що склалися в суспільстві, та виконують функцію правової компенсації певним категоріям осіб з метою якнайшвидшої ліквідації наслідків соціальної нерівності [1, с. 77].

Однак позитивні дії не повинні мати безумовного й абсолютного характеру та передбачати автоматичне надання переваг. Спеціальні заходи мають застосовуватися за умови наявності об'єктивних i розумних пояснень ї необхідності в демократичному суспільстві, мати обмежений характер, a їх тривалість і зміст повинні залишатися в межах, необхідних для подолання відповідного прояву нерівності. Інакше вони самі можуть стати підставою для зворотної дискримінації.

У межах статті проаналізуємо, які позитивні дії застосовуються державою у виборчій сфери, до яких наслідків призводить їх упровадження та за яких умов позитивна дискримінація не обертається у зворотну.

Допустимість уведення позитивних заходів на користь осіб, що перебувають у несприятливому становищі, підтверджується рекомендаціями низки моніторингових органів, уповноважених здійснювати тлумачення правозахисних договорів у рамках системи $\mathrm{OOH}$ [2, с. 39]: Комітет ООН з ліквідації расової дискримінації, Загальна рекомендація № 32: значення і зміст спеціальних заходів за Міжнародною конвенцією про ліквідацію усіх форм расової дискримінації [3]; Комітет ООН з економічних, соціальних і культурних прав, Загальний коментар № 13: право на освіту [4]; Комітет ООН з ліквідації дискримінації щодо жінок, Загальна рекомендація № 25: стаття 4 (1) Конвенції» (тимчасові особливі заходи) [5]; Комітет $\mathrm{OOH}$ з прав людини, Загальний коментар № 18: недискримінація [6]; Комітет ООН з ліквідації расової дискримінації, Загальна рекомендація № 30 щодо дискримінації негромадян [7].

Прямо передбачають можливість уведення позитивних заходів й антидискримінаційні директиви $\in C[2$, с. 37]: Директива, що імплементує принцип рівного поводження з людьми, незалежно від їхнього расового або етнічного походження (ст. 5) [8]; Директива, що забезпечує застосування принципу рівних можливостей і рівного ставлення до чоловіків і жінок у питаннях працевлаштування та зайнятості (ст. 7) [9]; Директива, що забезпечує застосування 


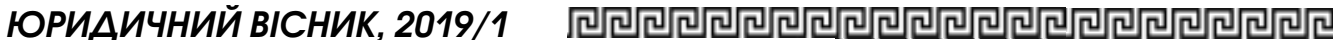

принципу рівного ставлення до чоловіків і жінок у доступі до товарів і послуг, а також у постачанні (ст. 6) [10].

Протокол № 12 до Конвенції про захист прав людини і основоположних свобод у Преамбулі підтверджує, «що принцип недискримінації не стоїть на заваді Державам-учасницям уживати заходів для сприяння повній і реальній рівності, якщо ці заходи є об’єктивно й обгрунтовано виправданими» [11]. У свою чергу, практика Європейського суду прав людини зазначає, що право на свободу від дискримінації в користуванні правами, що гарантовані, є порушеним i тоді, коли держави не забезпечують різного ставлення до осіб, ситуації яких значною мірою відрізняються [12].

Концепція «позитивної дискримінації» використовується в контексті національного антидискримінаційного законодавства. Вона передбачає використання позитивних дій - спеціальних тимчасових заходів, що мають правомірну, об'єктивно обгрунтовану мету, спрямовану на усунення юридичної чи фактичної нерівності в можливостях для особи та/або групи осіб реалізовувати на рівних підставах права і свободи, надані їм Конституцією й законами України [13].

Закон України «Про засади запобігання та протидії дискримінації в Україні» зараховує позитивні дії до основних напрямів державної політики в цій сфері (ст. 7). Для досягнення мети з подолання нерівності можуть бути використані різні види позитивних дій, а саме: спеціальний захист з боку держави окремих категорій осіб, які потребують такого захисту; здійснення заходів, спрямованих на збереження ідентичності окремих груп осіб, якщо такі заходи є необхідними; надання пільг і компенсацій окремим категоріям осіб у випадках, передбачених законом; установлення державних соціальних гарантій окремим категоріям громадян; особливі вимоги, передбачені законом, щодо реалізації окремих прав осіб (ст. 6).

У виборчій сфері позитивні дії можуть проявлятися через різні заходи: квотування; преференційний режим для представників уразливих груп; резервування за представниками меншин чи осіб із захищеною ознакою певної кількості місць, зокрема, у виборних органах; територіальна організація виборів 3 урахуванням міноритарного критерію, цілеспрямовані інклюзивні стратегіi, роз'яснювальна робота й інформаційно-пропагандистські програми тощо.

Проаналізуємо позитивні дії у виборчій сфері на прикладі територіальної організації виборів з урахуванням міноритарного критерію.

Зазвичай термін «джеррімендеринг» має негативний підтекст, оскільки пов'язаний із викривленням репрезентативності виборців у представницькому органі, але виборча географія може також використовуватися в цілях, які сприймаються як соціально позитивні, зокрема це стосується іï застосування в інтересах національних меншин, коли межі округів проводяться в такий спосіб, що допомагає їм забезпечити кількість мандатів пропорційно їх відсотку в чисельності населення країни. Застосування керованих меж виборчого округу для позитивних соціальних цілей отримало назву «позитивний джеррімендеринг», який покликаний виправити дискримінацію та гарантувати, що расові й етнічні меншості одержать місця в представницькому органі.

Наприклад, у Франції мета позитивного джеррімендерингу полягає в тому, щоб зробити голос сільського виборця вагомішим, ніж голос міського, створивши в сільській місцевості більше виборчих округів з меншою кількістю виборців, ніж у містах. У результаті при рівній кількості виборців, що проживають у міській і сільській місцевості, в останній може бути утворено більше округів. Відомий французький професор Жорж Ведель, образно висловився щодо цієї системи: «Сенат - це посольство провінційної Франції в Парижі» [14]. Чинна у Франції мажоритарна система залишає населення густонаселених промислових районів (Паризький район, Марсель, Ліон тощо) у меншості, порушуючи принцип рівного виборчого права. 


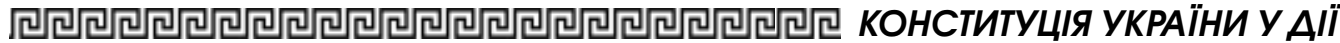

Доволі активно зазначена практика використовується в Сполучених Штатах Америки у вигляді так званих виборчих округів «більшість-меншості», цілеспрямовано створених за національною або расовою ознакою. Наприклад, у зв'язку з історичними конфліктами між Хопі та Навахо законодавчі збори штату Аризона прийняли рішення про забезпечення кожній із народностей американських індіанців резервації власного представника в законодавчому органі. Оскільки резервація Хопі повністю оточена резервацією Навахо, законодавчі збори штату створили незвичайну конфігурацію виборчого округу, що проходить уздовж ріки тонкою ниткою в кілька сотень миль, щоб з'єднати два регіони Навахо в Другий виборчий округ штату Аризона [15].

Водночас американський виборчий досвід свідчить про неоднозначність такої практики, що мала й негативні наслідки у вигляді зворотної дискримінації.

Зворотна дискримінація - це дискримінація членів домінуючої, мажоритарної групи на користь представників меншості або групи, що знаходиться в історично несприятливому становищі. Виникнення такого виду дискримінації зумовлено як недоліками в юридичному визначені обмежень позитивної дискримінації, так і в зловживанні тимчасовими правовими перевагами з боку раніше уразливих груп, тобто рівності намагаються досягнути через нерівність.

Один із таких випадків став предметом розгляду Верховним Судом Сполучених Штатів Америки. Мова йде про справу «Шоу проти Рено» (Shaw v. Reno, 1993), рішення по якій установило прецедент щодо поєднання процесу створення виборчих округів i расової політики. Предметом суперечки стало районування виборчих округів у штаті Північна Кароліна після перепису населення 1990 р. Спочатку карта штату передбачала один виборчий округ «більшість-меншості» 3 перевагою афроамериканського населення, але, на думку Міністерства юстиції, для поліпшення репрезентативності чорношкірих виборців мав бути створений ще один такий округ. Переглянувши карту територіальної організації виборів, легіслатура штату визначила додатковий округ «більшість-меншості», який мав незвичайну форму: довжиною в 160 миль (260 км), хвилястої конфігурації, він проходив через весь штат по автомагістральних шляхах та об'єднував різні території лише за однією ознакою - більшість афроамериканського населення. На думку заявників - білих виборців, такий спосіб районування був проявом дискримінації та мав на меті лише обрання до Конгресу афроамериканського представника. Суд вирішив, якщо «дивна» форма виборчого округу не пояснюється нічим іншим як расовою ознакою, то створення такого округу має здійснюватися в суворій відповідності до конституційних положень про недопущення дискримінації, а органи, які визначають межі округів з урахуванням расової ознаки, повинні забезпечити дотримання закону про виборчі права та реалізацію інтересів інших категорій виборців [16].

Ефективна участь національних меншин у суспільно-політичному житті $€$ одним із найважливіших складників мирної та демократичної держави. Як свідчить досвід, накопичений у Європі та поза іiі межами, для стимулювання такої участі державам нерідко доводиться створювати спеціальні механізми.

Рамкова конвенція про захист національних меншин передбачає створення державою необхідних умов для ефективної участі осіб-представників національних меншин у культурному, соціальному, економічному житті й у державних справах [17]. У свою чергу, Лундські рекомендації ОБСЕ про ефективну участь національних меншин у суспільно-політичному житті [18] та Інструкція ОБСЕ/БДІПЛ щодо сприяння участі національних меншин у виборчому процесі [19] пропонують закріплення положень, відповідно до яких держава повинна забезпечити меншинам доступ до реальних важелів впливу на рівні центральної влади, а за потреби забезпе- 
чити й особливі механізми, зокрема, під час виборчого процесу.

Одним із важливих складників механізму реалізації прав національних меншин та етнічних спільнот на ефективне політичне представництво $є$ врахування їх компактного проживання під час формування виборчих округів. У рекомендаціях Венеціанської комісіі підкреслюється важливість цього процесу й зазначається, що виборчі округи (ï розмір i конфігурація) мають бути утвореними з урахуванням необхідності заохотити представників національних меншин узяти участь у виборах [20].

В окремих європейських державах такі механізми встановлені, зокрема, під час проведення парламентських виборів в Іспанії, Данії, Фінляндії, Кіпрі, застосовується практика включення представників національних меншин до партійних списків (Австрія, Бельгія, Фінляндія, Німеччина (частково), Греція, Латвія, Литва, Польща, Словаччина); існує практика врахування в процесі утворення виборчих округів місць компактного проживання національних (мовних) меншин; за окремими регіонами закріплюється певна кількість місць у парламенті (в Даніі - місця для представників Фарерських островів і Гренландії, у Фінляндії - місця для представників Аландських островів); в окремих країнах можна створювати регіональні партіі, які представляють інтереси національних меншин (Австрія, Бельгія, Велика Британія, Греція, Данія, Естонія (3 партії, які представляють російську нацменшину), Іспанія (партії в Каталонії та Країні Басків) [21, с. 194]. Цікавим є досвід Хорватії, в якій для голосування виборців-представників національних меншин утворюється окремий виборчий округ, межі якого збігаються 3 межами території Хорватії (округ № 12), а право на представництво мають такі меншини: угорська (1 депутат), італійська (1 депутат), чеська і словацька (1 депутат), австрійська, болгарська, німецька, польська, ромська, румунська, русинська, російська, турецька, українська, молдавська та єврейська (1 депутат), албанська, боснійська, чорногорська, македонська та словенська (1 депутат) [22] .

Однак тривалий характер застосування спеціальних заходів може викликати зворотну дискримінацію. Один із таких випадків був предметом розгляду ЄСПЛ у справі Sejdić i Finci проти Боснії й Герцеговини [23].

Суд розглянув правило про виключення, відповідно до якого лише особи, які заявляють про свою належність до «державоутворювального народу», мали право балотуватися на виборах до палати народів (другої палати парламенту країни). Тому потенційні кандидати, які відмовлялися заявляти про таку свою належність, не могли балотуватися. Суд зазначив, що це правило про виключення мало щонайменше одну мету, яка загалом відповідала загальним цілям Конвенції, а саме цілям відновлення миру. На момент упровадження оскаржуваних конституційних положень у країні діяло дуже хитке перемир'я. Положення мали на меті забезпечити припинення жорстокого конфлікту, який супроводжувався актами геноциду та етнічними чистками. Характер конфлікту був таким, що погодження положення про «державоутворювальні народи» (а саме: бошняки, хорвати й серби) було потрібним для забезпечення миру. Це могло пояснити, але не обов'язково виправдати відсутність представників інших громад (зокрема ромів і євреїв) на мирних переговорах, а також зацікавленість учасників переговорів у реальній рівності між «державоутворювальними» народами в постконфліктному суспільстві. Однак у Боснії й Герцеговині відбулися значні позитивні зміни з часів Дейтонської угоди. Крім того, ратифікувавши Конвенцію та Протоколи до неї без застережень, держава-відповідач добровільно погодилася забезпечити відповідність установленим стандартам. Відповідно, Суд дійшов висновку, що постійне позбавлення заявників (які мали ромське та єврейське походження) права балотуватися на вибо- 
рах не мало об'єктивного й розумного виправдання, а тому було порушенням статті 14 Конвенції, взятої в поєднані зі статтею 3 Протоколу № 1 .

У справі Zornić проти Боснї й Герцеговини [24] Суд із тих самих підстав установив порушення статті 3 Протоколу № 1 через неможливість заявника балотуватися на виборах до палати народів і на виборах президента, зазначивши, що мала місце значна затримка у виконанні його рішення у справі Sejdić i Finci проти Босніi й Герцеговини, а також те, що оскаржуване порушення було прямим результатом цієї затримки. Він установив, що через 18 років після завершення трагічного конфлікту в Боснії й Герцеговині настав час установити політичну систему, спроможну надати всім громадянам країни право висувати свою кандидатуру на виборах до палати народів і на пост президента без різниці щодо етнічного походження.

Підсумовуючи, зазначимо, що позитивна дискримінація пов'язана із застосуванням короткочасних і виняткових заходів, які, хоча зовнішньо виглядають як дискримінаційні, насправді спрямовані на подолання упереджень щодо осіб, які зазвичай потерпають від дискримінаціï. Відмінне ставлення, що вводиться позитивними діями, розглядається не як окремий вид дискримінації, а як виняток із правила про заборону дискримінації. Натомість будь-яке обмеження права на рівне поводження варто оцінювати дуже критично, щоб не допустити виникнення правового дисбалансу в майбутньому.

Наведені приклади зворотної дискримінації викликають необхідність під час застосування позитивних дій відповісти на запитання, як можна гарантувати їх використання на справедливих, рівноправних, об'єктивних і неупереджених засадах.

Необхідною умовою застосування позитивних дій $€$ розроблення правового механізму, завдяки якому стає зрозумілим: а) чому позитивні дії стали елементом антидискримінаційного зако- нодавства й політики; б) які заходи використовуються як позитивні дії й чому інші альтернативи не були застосовані; в) коли та як довго потрібно використовувати позитивні діі; г) який правовий контроль існує для запобігання виникненню зворотної дискримінації.

Ключові слова: вибори, зворотна дискримінація, позитивні дії, позитивна дискримінація, уразливі групи.

Стаття присвячена позитивній i зворотній дискримінації у виборчій сфері. Аналізуються позитивні діï, що застосовуються державою стосовно уразливих груп, i наслідки, до яких призводить їх упровадження, зокрема зворотна дискримінація.

Статья посвящена положительной и обратной дискриминации в избирательной сфере. Анализируются положительные действия, применяемые государством по отношению к уязвимым группам, и последствия, $\kappa$ которым приводит их внедрение, в частности обратная дискриминация.

The article is devoted to positive and reverse discrimination in the electoral field. It analyzes the affirmative actions taken by the state in relation to vulnerable groups and the consequences to which they are implemented, in particular, reverse discrimination.

\section{Література}

1. Питання заборони та протидії дискримінаціі : методичні рекомендації та практичний посібник з аргументації для юристів / упорядник : Г. Христова. Київ, 2015, 112 c. URL: file: / / / C: / Users / User / Downloads / GuidelinesFinal26-05.pdf.

2. Посібник з європейського антидискримінаційного права. Київ: ТОВ K.I.C., 2013. 196 c. URL: file: / / / C: / Users /User/ Downloads/FRA_Case_Law_Handbook_ $U K R_{-} W E B \%$ 20(2) pdf.

3. Комітет ООН з ліквідації расової дискримінації, Загальна рекомендація № 32: значення $i$ зміст спеціальних заходів за Міжнародною конвениією про ліквідащію усіх форм расової дискримінації, UN Doc. CERD/C/GC/32, 24 вересня 2009 p. URL: 
file: / / / C: / Users / User / Downloads / G0945152.pdf.

4. Комітет ООН з економічних, соціальних $i$ культурних прав, Загальний коментар № 13: право на освіту, UN Dос. E/C.12/1999/10, 8 грудня 1999 p. URL: https: / / undocs.org/ru/E/C.12/1999/ 10.

5. Комітет ООН з ліквідації дискримінації щодо жінок, Загальна рекомендація № 25: статmя 4 (1) Конвениі (тимчасові особливі заходи), UN Doc. A/59/38(SUPP), 18 березня 2004 p. URL: https: / / undocs.org / ru/A/59/38(SUPP).

6. Комітет ООН з прав людини, Загальний коментар № 18: недискримінація, UN Doc. A/45/40 (Vol. I.) (SUPP). URL: https: / / undocs.org / ru/A/45/40(VOL.II) (SUPP), 10 листопада 1989 року.

7. Комітет ООН з ліквідаціі расової дискримінації, Загальна рекомендація № 30 щодо дискримінаиї̈ негромадян. UN Doc. HRI/GEN/1/Rev.7/Add.1, 4 травня 2005 p. URL: https: / / undocs.org / ru / HRI/ GEN / 1 / Rev.7 / Add.1.

8. Директива № 2000/43/ ЕС Ради EC, що імплементуе принщип рівного поводження з людьми, незалежно від їх расового або етнічного походження, від 29 червня 2000 p. URL: https: / / zakon.rada.gov.ua/ laws / show/994_a65.

9. Директива 2006/54/EC Европейського Парламенту та Ради, щз забезпечує застосування принципу рівних можливостей та рівного ставлення до чоловіків $i$ жінок у питаннях працевлаштування ma зайнятості, від 5 липня 2006 p. URL: http: / / old.minjust.gov.ua/45891

10. Директива Ради 2004/113/EC, що забезпечуе застосування принципу рівного ставлення до чоловіків $i$ жінок у достуni до товарів $i$ послуг, а також у іхньомy постачанні, від 13 грудня 2004 p. URL: http: / / old.minjust.gov.ua/45891.

11. Протокол № 12 до Конвениії про захист прав людини $i$ основоположних свобод (ETS $N$ 177) від 04.11.2000. URL: https: / / zakon.rada.gov.ua/laws / show /994_537.

12. Thlimmenos v. Greece [GC], no. 34369/97, \& 44, ECHR 2000-IV. URL: https: / / hudoc.echr.coe.int.

13. Про засади запобігання та протидіï дискримінації в Україні : Закон України від 6 вересня 2012 р. № 5207-VI. URL: https: / / zakon.rada.gov.ua/laws/show/5207-17.

14. Франция: анализ избирательного законодательства в контексте соблюде- ния общедемократических стандартов и прав человека / Центр Мониторинга Демократических Процессов «Кворум». URL: http: / / www.cmdp-kvorum.org / democratic-process / 62 .

15. Cooper M. 5 Ways to Tilt an Election. URL: http://graphics8.nytimes.com/ packages / pdf / weekinreview/20100925redistricting-graphic.pdf.

16. U.S. Supreme Court Shaw v. Reno, 509 U.S. 630 (1993) 509 U.S. 630 Ruth O. Shaw, Et Al., Appellants v. Janet Reno, Attorney General Et Al. Appeal from the United States District Court for the Eastern District of North Carolina no. 92-357 Argued April 20, 1993 Decided June 28, 1993. URL: http: / / caselaw.lp.findlaw.com / cgi-bin / getcase. l ? court $=U S \& v o l=509 \&$ invol $=630$.

17. Рамкова конвенція про захист національних меншин від 1 лютого 1995 р. Oфiційний вісник України. 2013. № 75. Cт. 2804.

18. Лундські рекомендації про ефективну участь національних меншин у суспільно-політичному житті з пояснювальними примітками. URL: http://wwш.osce.org/ uk/hcnm/32255.

19. Заключний звіт ОБСЕ/БДІПЛ, Парламентські вибори 31 березня 2002 р., Україна. URL: http://wwr.osce.org/uk/ odihr/elections / ukraine/ 14947.

20. Summary Report on Participation of Members of Minorities in Public Life. URL: http: / / ww.venice.coe.int / docs / 1998/ CDL-MIN(1998)001rev-e.pdf.

21. Лихач Ю.Ю. Забезпечення представництва національних меншин у виборних органах Європейського Союзу. Наукові записки Iнституту політичних $і$ етнонаиіональних досліджень ім. І.Ф. Кураса НАН України. Київ, 2008. Bun. 41. С. 186-196.

22. Ковриженко Д.С. Утворення одномандатних округів для проведення чергових парламентських виборів 2012 року: основні проблеми та можливі шляхи іх вирішення : Аналітична записка директора правових програм Лабораторіі законодавиих ініціатив. URL: http:// parlament.org.ua/upload/docs / IFESNote $\% 20$ on $\% 20$ election $\% 20$ districts_.pdf.

23. Sejdić and Finci v. Bosnia and Herzegovina [GC], nos. 27996/06 and 34836/06, ECHR 2009. URL: https:// hudoc.echr.coe.int.

24. Zornić v. Bosnia and Herzegovina, no. 3681/06, 15 July 2014. URL: https:// hudoc.echr.coe.int. 